\title{
COMMENTS
}

\section{STUFFING THE RABBIT BACK INTO THE HAT: LIMITED WAIVER OF THE ATTORNEY-CLIENT PRIVILEGE IN AN ADMINISTRATIVE AGENGY INVESTIGATION}

The attorney-client privilege is the oldest of the common-law privileges. ${ }^{1}$ It protects information that clients communicate to their lawyers, ${ }^{2}$ but it exists only so long as the clients are willing to preserve the confidentiality of the underlying communications. ${ }^{3}$ If a client voluntarily ${ }^{4}$ breaches the confidentiality and reveals the contents of the privileged communications to a third party, the privilege is waived. ${ }^{5}$ When the client is a corporation, ${ }^{6}$ however, and the privileged documents ${ }^{7}$ are disclosed to the Securities and Exchange Commission (SEC) in response to an agency request or subpoena, ${ }^{8}$ some courts have found the usual rule of waiver to be too harsh, and have carved out an exception to the general principle

1 Upjohn Co. v. United States, 449 U.S. 383, 389 (1981) (citing 8 J. WiGMIORE, EVIDENCE $\$ 2290$ (McNaughton rev. 1961)). note 31 .

2 For a fuller definition of the scope of the attorney-client privilege, see infra

3 For any privilege to exist, "[t]he communications must originate in a confidence that they will not be disclosed." $8 \mathrm{~J}$. Wigmore, supra note $1, \S 2285$, at 527 (emphasis in original).

4 Production that is involuntary or compelled may not result in a waiver of the attorney-client privilege. See infra notes 71-74 and accompanying text.

5 "A waiver may be effectuated by a disclosure of confidential information. Once the confidential matter has been disclosed, it is no longer a secret and the privilege which might be claimed . . disappears." Magida ex rel. Vulcan Detinning Co. v. Continental Can Co., 12 F.R.D. 74, 77 (S.D.N.Y. 1951), aff'd, 231 F.2d 843 (2d Cir.), cert. denied, 351 U.S. 972 (1956). For further discussion of the principle of waiver, see infra text following note 59.

( "Courts have generally recognized that the attorney-client privilege applies to corporations ...." United States v. Upjohn Co., 600 F.2d 1223, 1226 (6th Cir. 1979), rev'd on other grounds, 449 U.S. 383 (1981); see also In re John Doe Corp., 675 F.2d 482, 487 (2d Cir. 1982) ("[The Supreme Court in] Upjohn affirmed the assumption that a corporation may assert the privilege on its behalf.") (citation omitted).

T "Documentary evidence of confidential communications is necessarily privileged as much as testimonial evidence." Colton v. United States, 306 F.2d 633, 639 (2d Cir. 1962), cert. denied, 371 U.S. 951 (1963).

8 The SEC has the power not only to request a corporation's cooperation with an informal investigation, but also to "subpena witnesses, take evidence, and require the production of any books, papers, or other documents which the Commission deems relevant or material" to its investigation. 15 U.S.C. $\$ 77 \mathrm{~s}(\mathrm{~b})$ (1976); see also 15 U.S.C. $\$ 78 \mathrm{u}(\mathrm{c})$ (1976) (judicial enforcement of SEC's investigative power). 
by allowing a "limited waiver" 9 of the attorney-client privilege.10 Under the doctrine of limited waiver, a corporation may release a privileged document to the SEG without losing the protection of the attorney-client privilege as against other parties. The corporation itself cannot be forced to relinquish the privileged material, and can prevent the SEC from surrendering the material to anyone else by requiring the agency to agree to honor the corporation's privilege before the corporation complies with the agency subpoena. ${ }^{11}$ Under these conditions, neither a private party nor another regulatory agency ${ }^{12}$ later may demand production of the document in a separate proceeding without interposition of the privilege.

Proponents of the doctrine of limited waiver, such as the Eighth Circuit in Diversified Industries, Inc. v. Meredith, ${ }^{13}$ contend that limited waiver serves two goals: promoting the use of outside counsel to conduct internal corporate investigations, ${ }^{14}$ and enhancing the SEC's regulatory function by encouraging production of documents to the agency.15 Critics of limited waiver, such as the District of Columbia Circuit in Permian Corp. v. United States, ${ }^{16}$ argue that the doctrine is inconsistent with the purposes and principles behind the attorney-client privilege, ${ }^{17}$ and that the public policies of en-

9 The language of "limited waiver" was first introduced in Diversified Indus. v. Meredith, 572 F.2d 596, 611 (8th Cir. 1978) (en banc), and followed in subsequent cases. See infra text following note 80 .

10 See Diversified, 572 F.2d at 611; In re ITV Sec. Litig., 89 F.R.D. 595, 615 n.13, 620-21 (N.D. Tex. 1981); Byrnes v. IDS Realty Trust, 85 F.R.D. 679, 685-89 (S.D.N.Y. 1980); In re Grand Jury Subpoena Dated July 13, 1979, 478 F. Supp. 368, 372-73 (E.D. Wis. 1979); cf. In re Sealed Case, 676 F.2d 793, 824 (D.C. Cir. 1982) (limited waiver permissible if party expressly reserves right to assert privilege in subsequent proceedings); Teachers Ins. \& Annuity Ass'n of Am. v. Shamrock Broadcasting Co., 521 F. Supp. 638, 646 (S.D.N.Y. 1981) (same). But see Permian Corp. v. United States, 665 F.2d 1214, 1219-22 (D.C. Cir. 1981); In re Weiss, 596 F.2d 1185, 1186 (4th Cir. 1979); In te Penn Cent. Commercial Paper Litig., 61 F.R.D. 453, 464 (S.D.N.Y. 1973); cf. In re John Doe Corp., 675 F.2d 482, 489 (2d Cir. 1982) (disclosure of corporate documents to underwriter for commercial purposes results in general waiver).

11 This is precisely what the plaintiff corporation attempted to do (albeit unsuccessfully) in Permian Corp. v. United States, 665 F.2d 1214 (D.C. Cir. 1981). See infra note 104 and accompanying text.

12 The discussion of limited waiver in this Comment focuses on federal administrative agencies and the attorney-client privilege in the federal courts, but the analysis might apply equally well to state administrative agencies.

13572 F.2d 596 (8th Cir. 1978) (en banc). For a more thorough discussion of Diversified, see infra text following note 80 .

14 See, e.g., Diversified, 572 F.2d at 611.

15 See, e.g., Byrnes v. IDS Realty Trust, 85 F.R.D. 679, 688 (S.D.N.Y. 1980). 18665 F.2d 1214 (D.C. Cir. 1981).

17 See id. 1220 . 
couraging internal corporate investigations and facilitating the SEC's function cannot outweigh the judicial policy of admitting all relevant material into evidence. ${ }^{18}$

This debate has taken on greater significance in light of the Supreme Court's recent decision in Upjohn Co. v. United States ${ }^{18}$ expanding the definition of the corporate client beyond the "control group" test ${ }^{20}$ that had been advocated in most ${ }^{21}$ circuits. ${ }^{22}$ The "control group" test had limited the application of the attorneyclient privilege in the corporate context to those employees who were in a position to take action on the legal advice rendered. By permitting the attorney-client privilege to attach to communications between attorneys and lower-level corporate employees, the Court in Upjohn effectively opened the door to increased self-policing of corporate malfeasance through the use of internal investigations conducted by outside counsel. ${ }^{23}$ Corporations may be more likely

18 See id. 1221-22.

19449 U.S. 383 (1981). An exhaustive discussion of the Upjohn decision's effect on the corporate attorney-privilege can be found in Gergaze, AttorneyCorporate Client Privilege, 37 Bus. LAw. 461 (1982).

20 Upjohn, 449 U.S. at 397. See generally Harper \& Row Publishers, Inc. v. Decker, 423 F.2d 487 (7th Cir. 1970), aff'd mem. by an equally divided Court, 400 U.S. 348 (1971); City of Philadelphia v. Westinghouse Elec. Corp., 210 F. Supp. 483, 485 (E.D. Pa.), petition for mandamus and prohibition denied sub nom. General Elec. Co. v. Kirkpatrick, 312 F.2d 742 (3d Cir. 1962), cert. denied, 372 U.S. 943 (1963).

21 In re Grand Jury Subpoena, 81 F.R.D. 691, 694 (S.D.N.Y. 1979).

22 See, e.g., United States v. Upjohn Co., 600 F.2d 1223 (6th Cir. 1979), rev'd, 449 U.S. 383 (1981); In re Grand Jury Investigation, 599 F.2d 1224 (3d Cir. 1979); Natta v. Hogan, 392 F.2d 686 (10th Cir. 1968).

23 At the time the Court decided Upjohn, two competing tests had been adopted by various circuits: the narrower "control group" test and the broader "subject matter" test. The subject matter test extends the protection of the attorney-client relationship to any

communication ... to the corporation's attorney ... where a [lowerlevel] employee makes the communication at the direction of his superiors in the corporation and where the subject matter upon which the attorney's advice is sought by the corporation and dealt with in the communication is the performance by the employee of the duties of his employment.

Harper \& Row, 423 F.2d at 491-92 (7th Cir. 1970). See 28 Drakse L. REv. 191, 191 (1978-79); 31 VAND. L. REv. 667, 669 (1978).

The Supreme Court, while rejecting the control group test, refused to adopt explicitly the subject matter test: "We decline to lay down a broad rule or series of rules to govern all conceivable future questions in this area, even were we able to do so." 449 U.S. at 386. Nevertheless, it is likely that lower courts will interpret Upjohn as an endorsement of the subject matter test. See Upjohn, 449 U.S. at 402-04 (Burger, C.J., concurring) (urging adoption of subject matter test); The Supreme Court, 1980 Term, 95 Harv. L. Rev. 17, 273 (1981). In any case, it seems clear that the Court intended the attorney-client privilege to extend to most communications that would be made in the course of an internal investigation by corporate counsel. See Upjohn, 449 U.S. at 391-92. 
to police themselves, however, if they are confident that the memoranda produced by outside counsel will not be used against them in future litigation. ${ }^{24}$

This Comment analyzes the arguments for and against the theory of limited waiver of the attorney-client privilege. Although the discussion focuses on limited waiver in the context of an SEC investigation, the conclusions drawn may be equally applicable to other administrative agencies. ${ }^{25}$ Part I discusses the theoretical considerations that led to judicial creation of the attorney-client privilege and their significance when the privilege is applied in the corporate context. Part II introduces the recent cases in the area of limited waiver, and outlines the issues that must be resolved. Part III discusses various formulations of limited waiver and analyzes the merits of the doctrine. This Comment concludes that the doctrine of limited waiver should be abandoned by the courts in favor of the usual rule of waiver.

\section{The Attorney-Gitent Privilege}

The effect of any privilege is to remove from the judicial process evidence that might be relevant to the resolution of a dispute. Consequently, privileged communications are generally disfavored in the law. ${ }^{26}$ Virtually no new judge-made privileges have been developed over the past one hundred years, and commentators have urged a narrow interpretation of existing privileges. ${ }^{2 \pi}$ Despite the costs that privileges impose on the evidentiary process, however, they are generally justified on the grounds that certain relationships are so valuable to society that they must be fostered by protecting their confidentiality. ${ }^{28}$ One such relationship is that between at-

24 A corporation incurs additional risks when it decides to conduct an internal investigation. "Usually, the expense and possible fruitlessness of discovery discourages potential litigants from bringing suits. But the existence of a detailed report, prepared with the cooperation of corporate directors and employees, greatly decreases the cost of discovery. As a result, corporate investigations increase the likelihood of later litigation." Note, Discovery of Internal Corporate Investigations, 32 Stan. L. Rev. 1163, 1178 (1980) (footnote omitted).

25 See infra text accompanying notes 127-45.

${ }^{20}$ In re Grand Jury Proceedings, Detroit, Michigan, August 1977, 434 F. Supp. 648, 649 (E.D. Mich. 1977), affd, 570 F.2d 562 (6th Cir. 1978).

27 See McCormack, HANDBOoK OF THE LAW OF EvmDence $\$ 77$, at 156 (E. Cleary $2 \mathrm{~d}$ ed. 1972).

28 See, e.g., G. LmLY, AN INTRODUCTION to THE LAw of EvIDENCE $\$ 86$, at 317 (1978).

Wigmore's treatise on evidence outlines four requirements for the existence of a privilege against the disclosure of communications: the communications must originate in confidence between the parties; the confidentiality must be essential to the relationship between the parties; the relationship must be one which society chooses to encourage; and the cost of disclosure must be greater than the in- 
torneys and their clients. ${ }^{29}$

The attorney-client privilege allows clients ${ }^{30}$ to prevent testimonial disclosure of confidential legal communications between themselves and their attorneys. ${ }^{31}$ Its protection extends to the con-

cremental benefit of achieving the correct judicial result. All four of these conditions must be present for a privilege to attach; the absence of one of the four requirements often can explain the failure to recognize a particular privilege, such as that of the doctor-patient relationship. Wigmore suggested that "the fallacy of recognizing [the doctor-patient privilege] . . . lies in the incorrect assumption that the second and fourth conditions are generally present." $8 \mathrm{~J}$. WIGMORE, supra note $1, \$ 2285$, at 527-28.

29 Wigmore felt that all four requirements for the existence of a privilege, see supra note 28 , were met in the attorney-client situation, noting that only the fourth condition could be "open to any dispute." $8 \mathrm{~J}$. WIGMORE, supra note 1, $\$ 2285$, at 528 .

30 The privilege belongs to the client rather than the attorney. $8 \mathrm{~J}$. WIGMORE, supra note $1, \$ 2321$, at 629 . The attorney, however, may assert the privilege on the client's behalf. Fisher v. United States, 425 U.S. 391,402 n.8 (1976). Moreover, as a matter of professional ethics the attorney is "duty bound" to assert the client's privilege. See Republic Gear Co. v. Borg-Warner Corp., 381 F.2d 551, 556 (2d Cir. 1967); see generally $2 \mathrm{~J}$. WeINSteIN \& M. Berger, WeINSTEIN'S EvIDENCE, If 503(c) [01], at 503-67 (1981).

312 D. Louiselx \& C. Muelleer, Federax Evidence $\$ 209$, at 518 (1978). The two most authoritative definitions of the attorney-client privilege are those of Dean Wigmore and Judge Wyzanski. Wigmore's summary states:

(1) Where legal advice of any kind is sought (2) from a professional legal advisor in his capacity as such, (3) the communications relating to that purpose, (4) made in confidence (5) by the client, (6) are at his instance permanently protected (7) from disclosure by himself or by the legal adviser, (8) except the protection be waived.

$8 \mathrm{~J}$. WIGmone, supra note $1, \$ 2292$, at 554 (footnote omitted). Judge Wyzanski's formulation states:

The privilege applies only if (1) the asserted holder of the privilege is or sought to become a client; (2) the person to whom the communication was made (a) is a member of the bar of a court, or his subordinate and (b) in connection with this communication is acting as a lawyer; (3) the communication relates to a fact of which the attorney was informed (a) by his client (b) without the presence of strangers (c) for the purpose of securing primarily either (i) an opinion on law or (ii) legal services or (iii) assistance in some legal proceeding, and not (d) for the purpose of committing a crime or tort; and (4) the privilege has been (a) claimed and (b) not waived by the client.

United States v. United Shoe Mach. Corp., 89 F. Supp. 357, 358-59 (D. Mass. 1950).

Another formulation is found in proposed Fed. R. Evid. 503, which defines the attorney-client privilege as follows:

(b) General rule of privilege. A client has a privilege to refuse to disclose and to prevent any other person from disclosing confidential communications made for the purpose of facilitating the rendition of professional legal services to the client, (1) between himself or his representative and his lawyer or his lawyer's representative, or (2) between his lawyer and the lawyer's representative, or (3) by him or his lawyer to a lawyer representing another in a matter of common interest, or (4) between representatives of the client or between the client and a representative of the client, or (5) between lawyers representing the client. 
fidential communication rather than the underlying facts ${ }^{32}$ : "a party cannot conceal a fact merely by revealing it to his lawyer." 33 In a functional sense, then, the attorney-client privilege protects only the attorney's fact-gathering efforts, assessment of the problem, and recommendations to the client. ${ }^{34}$

The attorney-client privilege is deeply rooted in common law ${ }^{35}$ as well as Roman law, ${ }^{36}$ making it the oldest of the privileges for confidential communications. ${ }^{37}$ The modern justification for the

Congress failed to approve proposed Fed. R. Evid. 503, replacing it with FED. R. Evm. 501. Rule 501 provides, in part, that "the privilege of a witness ... shall be governed by the principles of common law as they may be interpreted by the courts of the United States in the light of reason and experience." The effect of Rule 501, then, is to "[incorporate] state rules of privilege to govern state claims and a federal common law for federal claims." Hellerstein, Current Attorney-Client Privilege Issues, 4 A.L.I.-A.B.A. Course Materuars Jounnax, Dec. 1979, at 5, 6. See Trammel v. United States, 445 U.S. 40, 47 (1980). It has been suggested that proposed Rule 503 may nevertheless be consulted as to the limits of the privilege. See Transamerica Computer Co. v. IBM, 573 F.2d 646, 651 (9th Cir. 1978); In re Grand Jury Proceedings, Detroit, Michigan, August 1977, 434 F. Supp. 648, 650 n.1 (E.D. Mich. 1977), affd, 570 F.2d 562 (6th Cir. 1978).

32 [T] he protection of the privilege extends only to communications and not to facts. A fact is one thing and a communication concerning that fact is an entirely different thing. The client cannot be compelled to answer the question, "What did you say or write to the attorney?," but may not refuse to disclose any relevant fact within his knowledge merely because he incorporated a statement of such fact into his communication to his attorney.

City of Philadelphia v. Westinghouse Elec. Corp., 205 F. Supp. 830, 831 (E.D. Pa. 1962) (emphasis in original), quoted in Upjohn v. United States, 449 U.S. 383, 395-96 (1981).

33 State ex rel. Dudek v. Circuit Court, 34 Wis. $2 d$ 559, 580, 150 N.W.2d 387, 399 (1967), quoted in Upjohn, 449 U.S. at 396.

34 The privilege does not extend to the mere fact that the client has consulted or employed an attorney. See generally McCormrck, supra note $27, \$ \$ 89-90$, at 182-87.

$358 \mathrm{~J}$. WIGMORE, supra note $1, \S 2290$, at 542. But cf. Hazard, An Historical Perspective on the Attorney-Glient Privilege, 66 Caxr. L. Rev. 1061, 1070 (1978) ("the historical foundations of the privilege are not as firm as the tenor of Wigmore's language suggests"). According to Wigmore, the attorneyclient privilege under early English common law protected the lawyer's honor: a gentleman, it was felt, respected confidences that had been entrusted to him. $8 \mathrm{~J}$. WIGMORE, supra note $1, \$ 2290$, at 543 . Thus, the privilege belonged to the attorney rather than the client. See id. 544 .

36 Radin, The Privilege of Confidential Communication Between Lawyer and Client, 16 CaLTF. L. Rev. 487, 488 (1928).

$378 \mathrm{~J}$. Wigmone, supra note $1, \$ 2290$, at 542 . The courts, however, have thus far refused to recognize any constitutional right to the attorney-client privilege. See, e.g., Magida ex rel. Vulcan Detinning Co. v. Continental Can Co., 12 F.R.D. 74,76 (S.D.N.Y. 1951) (the attorney-client privilege "is without constitutional guarantee"), aff'd, 231 F.2d 843 (2d Cir.), cert. denied, 351 U.S. 972 (1956). But cf. United States v. Henry, 447 U.S. 264, 295 (1980) (Rehnquist, J., dissenting) ("the Sixth Amendment . . . protects the confidentiality of communications between the accused and his attorney"). The privilege may nevertheless have some constitutional basis in criminal, but not civil, cases through 
privilege is that clients would be deterred from confiding fully in their attorneys if they feared that attorneys could be compelled to disclose what had been said. ${ }^{38}$ The privilege "rests on the need for the advocate and counselor to know all that relates to the client's reasons for seeking representation if the professional mission is to be carried out." ${ }^{39}$ Wigmore points out that "[t]here is in civil cases often no hard and fast line between guilt and innocence," 40 and that disclosures to attorneys should therefore be encouraged to enable professional advocates to construct the best possible defense. ${ }^{41}$

The ultimate purposes of the privilege, therefore, are to promote lawful conduct and further judicial administration by facilitating legal consultation. ${ }^{42}$ As a number of commentators have noted, however, the privilege's benefits are "indirect and speculative," while the costs are "plain and concrete." 43 The privilege, for example, tends to force litigants to duplicate their investigative efforts, thus increasing the costs of discovery and litigation. ${ }^{44}$ More importantly, the attorney-client privilege, like all privileges, removes

an interrelationship with the fifth and sixth amendments. See State v. Kociolek, 23 N.J. 400, 415, 129 A.2d 417, 425 (1957); Note, The Attorney-Client Privilege: Fixed Rules, Balancing, and Constitutional Entitlement, 91 Harv. L. Rev. 464, 486 n.96 (1977).

$388 \mathrm{~J}$. WIGMORE, supra note $1, \S 2291$, at 545.

39 Trammel v. United States, 445 U.S. 40, 51 (1980). See Hazard, supra note 35 , at 1061:

The attorney-client privilege may well be the pivotal element of the modern American lawyer's professional functions. It is considered indispensable to the lawyer's function as advocate on the theory that the advocate can adequately prepare a case only if the client is free to disclose everything, bad as well as good. The privilege is also considered necessary to the lawyer's function as confidential counselor in law on the similar theory that the legal counselor can properly advise the client what to do only if the client is free to make full disclosure.

$408 \mathrm{~J}$. Wigmore, supra note $1, \$ 2291$, at 552 (emphasis deleted).

41 This analysis is equally applicable in criminal cases: a client might conceal all the facts and thereby miss a valid defense if the privilege were not available.

42 See Upjohn, 449 U.S. at 389. See also MODEL CODE OF EvDENCE RULE 210 comment (1942), quoted in $8 \mathrm{~J}$. WIGMore, supra note $1, \S 2291$, at 549 ("The social good derived from the proper performance of the functions of lawyers acting for their clients is believed to outweigh the harm that may come from the suppression of the evidence in specific cases.").

$438 \mathrm{~J}$. Wigmore, supra note $1, \$ 2291$, at 554 . See also $2 \mathrm{~J}$. WeINSTEen \& M. BERGER, supra note 30, $\{503[02]$, at 503-15 ("Th[e] assumption [of confidentiality] underlying the privilege is unverifiable"); Popkin, Client-Lawyer Confidentiality, 59 Tex. L. Rev. 755, $767 \mathrm{n} .91$ (1981) ("To my knowledge, there is no empirical research supporting or rejecting these assumptions. We cannot be completely sure that confidentiality is important either in encouraging use of lawyers or in helping the representative protect the client's rights."); Note, Attorney-Client Privilege for Corporate Clients: The Control Group Test, 84 HARv. L. Rev. 424, 425 n.7 (1970) (diffculty of finding empirical proof supporting the proposition that the privilege encourages more complete communication with counsel).

44 Note, supra note 24 , at 1165 . 
from the judicial process evidence that might be relevant to the resolution of a dispute, thus increasing the danger that cases will be wrongly decided for lack of information. ${ }^{45}$

Moreover, when the client is a corporation, ${ }^{46}$ the costs incurred by upholding the privilege are especially high. "[T] lawyer is a repository of information gathered from many sources within the corporation and available from no other single source." 47 Consequently, the difficulties of duplicating the information discoverable directly from the attorney are "greater as against corporations than they are when both responsibility and information are centralized in a single person." 48 A corporate claim of the privilege may therefore "lead to more of a loss of relevant evidence than when the privilege is invoked by an individual client." 49

The availability of the privilege in the corporate context may not even serve the purpose of furthering legal consultation. ${ }^{50}$ Corporate employees, for example, cannot depend on the attorney-client privilege to guarantee the confidentiality of their communications with corporate counsel because the privilege belongs to the corporate client, who may waive it without the employees' consent. ${ }^{51}$ As a result, the availability of the privilege may have little bearing on a corporate employee's decision to communicate with corporate counsel.52 Furthermore, the complexity of corporate transactions and the consequent need for day-to-day advice would seem to provide sufficient incentives for corporations to consult attorneys re-

45 Wigmore observed that the privilege is "an obstacle to the investigation of the truth." $8 \mathrm{~J}$. WrGMORE, supra note 1 , \$2291, at 554 .

46 Corporations may claim the benefit of the attorney-client privilege. See supra note 6. See also cases cited in Developments in the Law-Corporate Crime: Regulating Corporate Behavior Through Criminal Sanctions, 92 HaRv. L. REv. 1227, 1290 n.84 (1979). See generally 2 D. Lounsenc \& C. MunLLER, supra note 31, \$212, at 556; Simon, The Attorney-Client Privilege as Applied to Corporations, 65 YALE L.J. 953 (1956); Comment, The Privileged Few: The Attorney-Client Privilege as Applied to Corporations, 20 U.C.L.A. L. Rev. 288 (1972). But of. The Supreme Court, 1980 Term, supra note 23, at 273 (little precedent supports "assumption" that attorney-client privilege applies in corporate context).

47 Note, supra note 43 , at 427.

482 D. Loutseli \& C. Muer,er, supra note 31 , $\$ 212$, at 558.

492 J. WeINSTEIN \& M. Berger, supra note 30, 【503(b)[04], at 503-42 (1981); see Simon, supra note 46, at 955 ("Where corporations are involved ... the zone of silence grows larger.").

$50 \mathrm{Cf}$. The Supreme Court, $1980 \mathrm{Term}$, supra note 23, at 273-77 (because privilege applies only when communications would not otherwise occur, privilege may have no role to play in corporate setting).

51 See Sagor, The Attorney-Client and Work-Product Privileges: Protection and Assertion, in Business Crmases: A Gume for Corporate and Defense Counsel 188 (J. Gleckel, ed. I982).

52 Note, supra note 24, at 1172-74; see Note, supra note 43, at 428-29. 
gardless of the availability of the privilege. ${ }^{53}$ Hence, the benefits derived from extending the attorney-client privilege to corporations seem particularly slight. ${ }^{54}$

In general, the party asserting the privilege bears the burden of establishing all necessary elements of the privilege, including the confidential nature of the communication. ${ }^{55}$ "The sine qua non of the attorney-client privilege is . . . a confidence reposed-and effectively imposed-for the purpose of obtaining or furthering legal assistance." 56 Society "subordinate[s] its interest in the search for truth" $5 \tau$ only so long as the confidentiality that fostered the protected relationship is not breached. ${ }^{58}$ Thus, the element of confidentiality is not merely a threshold requirement, but must be maintained for the privilege to retain its vitality. ${ }^{50}$ A client's voluntary disclosure or consent to disclosure of confidential information to a third party ${ }^{60}$ waives the attorney-client privilege. ${ }^{01}$

\footnotetext{
53 See Note, supra note 37 , at 473.

54 But cf. 2 D. LouTselt \& C. MUELTER, supra note $31, \$ 212$, at 556:

It is in the public interest that corporations actively seek counsel on [taxation, environmental protection, and regulatory] matters; it is fair to hope, though sometimes no doubt the hope is vain, that lawyers will not by their counsel aid in avoiding the impact of such laws, but will instead aid in securing reasonable compliance.
}

55 See United States v. Tratner, 511 F.2d 248, 252 (7th Cir. 1975); In re Horowitz, 482 F.2d 72, 82 (2d Cir.), cert. denied, 414 U.S. 867 (1973); In re Grand Jury Subpoenas Dated April 19, 1978, 451 F. Supp. 969, 971 (E.D.N.Y. 1978).

56 In re Grand Jury Subpoena Duces Tecum Dated Nov. 16, 1974, 406 F. Supp. 381, 386 (S.D.N.Y. 1975).

57 In re Sealed Case, 676 F.2d 793, 807 (D.C. Cir. 1982).

58 See, e.g., In re Penn Cent. Commercial Paper Litig., 61 F.R.D. 453, 464 (S.D.N.Y. 1973) (footnote omitted): "[S]ecrecy and confidentiality are necessary to promote the relationship fostered by the privilege. Once the secrecy or confidentiality is destroyed ... the rationale for granting the privilege in the first instance no longer applies." The client, however, may often be less concerned with secrecy or confidentiality than with having the attorney-client relationship used against him. See, e.g., Diversified Indus. v. Meredith, 572 F.2d 596 (8th Cir. 1978) (en banc) (privilege asserted as to materials concerning a "slush fund" despite public knowledge thereof). Consequently, the client often seeks protection against discovery from the work-product doctrine as well as the attorney-client privilege. See, e.g., id.; see also Note, supra note 24. For a brief discussion of the work-product doctrine, see infra note 61 .

59 "One of the most critical attributes of the privilege is that it protects only communications which the client has made in confidence and has kept confidential." Teachers Ins. \& Annuity Ass'n of Am. v. Shamrock Broadcasting Co., 521 F. Supp. 638, 641 (S.D.N.Y. 1981) (emphasis added). See also McCormack, supra note $27, \$ 93$, at 194 n.14. ("[D]isclosure ... deprives a subsequent claim of privilege based on confidentiality of any significance.").

60 For purposes of the attorney-client privilege, a third party is "one who stands in a neutral or adverse position vis-a-vis the subject of the communication." In re Grand Jury Subpoena Duces Tecum Dated Nov. 16, 1974, 406 F. Supp. 381, 386 (S.D.N.Y. 1975) (emphasis added); see McCormarc, supra note $27, \$ 91$, at $188-89$.

61 United States v. AT\&T, 642 F.2d 1285, 1299 (D.C. Cir. 1980). The attorney-client privilege must be distinguished from the work-product doctrine, 
A waiver of the privilege may be express or implied, ${ }^{62}$ deliberate or unintentional; ${ }^{83}$ the onus of preserving secrecy is on the client. ${ }^{64}$ The waiver rule serves to ensure that the privilege, with its attendant costs to the judicial system, is "strictly confined within the narrowest possible limits consistent with the logic of its principle." ${ }^{\circ}$ The ultimate purpose of the privilege is to encourage clients to discuss secrets with and make declarations against interest to their attorneys, free from the fear that the attorneys will later be compelled to disclose these confidences. If clients themselves divulge such information to third parties, chances are that they would also have divulged it to their attorneys, even without the protection of the privilege. Thus, once a client has revealed privileged information to a third party, the basic justification for the privilege no longer applies, and the privilege is waived. ${ }^{68}$

which protects from discovery the "mental impressions, conclusions, opinions, or legal theories of an attorney . . concerning the litigation." FED. R. Crv. P. $26(\mathrm{~b})(3)$. The two privileges are not coextensive, although they are obviously related. The attorney-client privilege protects only "communications" between attorneys and clients, whereas the work-product doctrine shields notes and memoranda that have not been communicated. On the other hand, the workproduct doctrine protects only those materials prepared "with an eye toward litigation." Hickman v. Taylor, 329 U.S. 495, 511 (1947).

Of more particular relevance to the present discussion, the "mere showing of a voluntary disclosure to a third person ... should not suffice in itself for waiver of the work product privilege." AT\&T, 642 F.2d at 1299 (emphasis in original). Unlike the attorney-client privilege, the work-product doctrine

protects both the attorney-client relationship and a complex of individual interests particular to attorneys that their clients may not share. And because it looks to the vitality of the adversary system rather than simply seeking to preserve confidentiality, the work product privilege is not automatically waived by disclosure to a third party.

In re Sealed Case, 676 F.2d 793, 809 (D.C. Cir. 1982) (footnotes omitted).

62 E.g., G. LلwLY, supra note $28, \S 91$, at 334 ("Waiver may, of course, take place expressly; it may also result from implication, as where the client voluntarily reveals the communication to a judicial or legislative body or to a person not within the group acting on behalf of the attorney or client.") (footnote omitted).

${ }^{63}$ See In re Sealed Case, 655 F.2d 1298, 1300 (D.C. Cir. 1982); Suburban Sew 'N Sweep, Inc. v. Swiss-Bernina, Inc., 91 F.R.D. 254, 258 (N.D. Ill. I981); $8 \mathrm{~J}$. WIGMORE, supra note $1, \$ 2327$, at 636; Hooker, Lawyers' Responses to Audit Inquiries and the Attorney-Client Privilege, 35 Bos. LAw. 1021, 1027 (1980); Note, Limited Waiver of the Attorney-Client Privilege upon Voluntary Disclosure to the SEC, 50 FordhaM L. REv. 963, 968-70 (1982).

64 "[I]f a client wishes to preserve the privilege . . . he must take some affirmative action to preserve confidentiality." In re Horowitz, 482 F.2d 72, 82 (2d Cir.), cert. denied, 414 U.S. 867 (1973).

$658 \mathrm{~J}$. WigMore, supra note $1, \S 2291$, at 554.

${ }^{66}$ See Fisher v. United States, 425 U.S. 391, 403 (1976) (the attorney-client privilege "protects only those disclosures-necessary to obtain informed legal advice-which might not have been made absent the privilege"); In re Penn Cent. Commercial Paper Litig., 61 F.R.D. 453, 463-64 (S.D.N.Y. 1973). 
Another consideration underlying the waiver rule is that of fairness. Wigmore observed that "when [a client's] conduct touches a certain point of disclosure, fairness requires that his privilege shall cease whether he intended that result or not." ${ }^{87}$ Generally, the fairness argument has been applied in the form of the "subject matter" waiver rule: once a client has disclosed part of a privileged communication, the privilege is deemed waived as to all related communications. ${ }^{68}$ To allow clients to choose to reveal only certain parts of a communication-presumably, those parts most favorable to their cause-would be to convert the privilege from a "shield" to a "sword" 69 : the privilege could be used "offensively," to paint a "misleadingly one-sided" picture of the facts. ${ }^{70}$

One exception to the waiver rule holds that an involuntary disclosure does not waive the privilege. ${ }^{71}$ Thus, a client who has been compelled erroneously to divulge a privileged communication in one proceeding may still invoke the privilege in a subsequent action. ${ }^{2}$ Similarly, a disclosure made "without opportunity to as-

$678 \mathrm{~J}$. WTGMoRE, supra note $1, \$ 2327$, at 636 .

68 See Sagor, supra note 51 , at 147 (the attorney-client privilege, "once waived, is not divisible"); Note, supra note 63 , at 970 n.48, 971 . Courts apparently retain discretion not to impose the "subject matter" waiver rule where the client fails to make use of a disclosed communication. See Sealed Case, 676 F.2d at 809 n.54.

69 See Teachers Ins. \& Annuity Ass'n of Am. v. Shamrock Broadcasting Co., 521 F. Supp. 638, 641 (S.D.N.Y. 1981); Byrnes v. IDS Realty Trust, 85 F.R.D. $679,688-89$ (S.D.N.Y. 1980).

70 Teachers, 521 F. Supp. at 641. Accord, Sealed Case, 676 F.2d at 818.

${ }^{11}$ See, e.g., Transamerica Computer Co. v. IBM, 573 F.2d 646, 651 (9th Cir. 1978); Shaffer v. Below, 278 F.2d 619, 628 (3d Cir. 1968); Duplan Corp. v. Deering Milliken, Inc., 397 F. Supp. 1146, 1163 (D.S.C. 1974); United States v. New Wrinkle, 1954 Trade Cas. (CCH) $\mathbb{6} 67,883$, at 69,856 (S.D. Ohio 1954); Proposed Fed. R. Evid. 511-12; 3 JoNES ON EvmENCE $\$ 21.22$, at 804 n.14 (6th ed. 1972).

72 Proposed Fed. R. Evid. 512 states: "Evidence of a statement or other disclosure of privileged matter is not admissible against the holder of the privilege if the disclosure was (a) compelled erroneously or (b) made without opportunity to claim the privilege." On the effect of proposed but unadopted rules of evidence, see supra note 31 .

The advisory committee note to Rule 512, in discussing erroneously compelled disclosures, rejects the view that the holder of the privilege must "incur contempt of court and exhaust all legal recourse" in order to sustain the privilege. Proposed Fed. R. Evid. 512 advisory committee note. The committee note does, however, appear to contemplate that the compulsion must be judicial in order for the disclosure to be deemed voluntary; mere intimidation would not seem to be enough. Id. ("The modest departure from usual principles of res judicata is justified by the advantage of having one simple rule, assuring at least one opportunity for judicial supervision in every case."). See also McCormrcr, supra note 27 , $\$ 93$, at 195 (arguing that when clients are asked on cross-examination about communications with their lawyers, and they respond without asserting the privilege, such testimony is a voluntary disclosure waiving the privilege). Cf. 8 J. WIGMORE, supra note $1, \$ 2270$, at 417 (where witness has properly claimed privilege against self-incrimination and claim has been erroneously overruled, 
sert the privilege" 73 is generally considered not to trigger the waiver rule. Once a client makes a considered choice to divulge a privileged communication, however, the privilege is waived and cannot be regained. ${ }^{74}$

In sum, the fundamental justification for the attorney-client privilege is to encourage clients to divulge confidences to their attorneys. The theory is that attorneys can defend their clients properly in court only if they are apprised of all relevant information, incriminating as well as exculpatory. The rationale for the privilege further assumes that clients will confide in their attorneys only if they know that the attorneys cannot be compelled to breach the confidentiality of the attorney-client relationship. If the client voluntarily breaches that confidentiality, the privilege is waived automatically.

\section{The Gase Law on Limited Waiver}

The principle of limited waiver of the attorney-client privilege is a relatively recent innovation. The issue has arisen most often in situations where corporations have, either of their own volition ${ }^{75}$ or at the suggestion of the $\mathrm{SEC}^{76}$ retained outside counsel to investigate suspected instances of corporate misconduct. The corporations have then voluntarily surrendered the reports resulting from these investigations to the SEC as part of the Commission's "voluntary disclosure" program.77 This program saved the SEC staff the

evidence of testimony is inadmissible against witness in any subsequent proceeding). See infra text accompanying notes 134-45.

73 Proposed Fed. R. Evid. 512(b). Examples of such inadvertent disclosure are "disclosure by an eavesdropper, by a person used in the transmission of a privileged communication, by a family member participating in psychotherapy, or privileged data improperly made available from a computer bank." Id. advisory committee note. See, e.g., Dunn Chem. Corp. v. Sybron Corp., 1975-2 Trade Cas. (CCH) I60,561, at 67,463 (S.D.N.Y. 1975). But see Underwater Storage, Inc. v. United States Rubber Co., 314 F. Supp. 546, 549 (D.D.C. 1970).

74 The traditional standard of waiver, particularly waiver of a constitutional right, is "the intentional relinquishment of a known right or privilege." Johnson v. Zerbst, 304 U.S. 458, 464 (1938). This standard does not apply in the confidential privilege situation, where "knowledge or lack of knowledge of the existence of the privilege appears to be irrelevant." Proposed Fed. R. Evid. 511 advisory committee note. See also $8 \mathrm{~J}$. WIGMORE, supra note $1, \$ 2327$, at 636 . Cf. supra note 37 .

${ }_{75}$ See, e.g., Diversified Indus., Inc. v. Meredith, 572 F.2d 596, 600-0I (8th Cir. 1977).

76 See, e.g., In re Sealed Case, 676 F.2d 793, 801 (D.C. Cir. 1982).

77 For a fuller discussion of the voluntary disclosure program, see id. 800-01, 818-20; Block \& Barton, Internal Corporate Investigations: Maintaining the Confidentiality of a Corporate Client's Communications with Investigative Counsel, 35 Bus. Law. 5, 6, 17-19 (1979). 
time and energy they would otherwise have spent conducting their own investigations. The participating corporations benefited because the SEC offered them leniency and a chance to avoid an embarrassing formal investigation. ${ }^{78}$ When the corporations have later become embroiled in litigation, however, they have attempted to shield the investigative reports and underlying documentation from discovery, arguing that their disclosure to the SEC should not be deemed to have breached the confidentiality essential to the continuation of the attorney-client privilege.

\section{A. Diversified and Its Progeny}

Although the theory of limited waiver was first raised in court in $1973,{ }^{79}$ it did not find judicial acceptance until the Eighth Circuit considered Diversified Industries $v$. Meredith, ${ }^{80}$ in 1977. Diversified arose after a proxy fight at the company revealed that Diversified might have maintained a "slush fund" for bribing purchasing agents of other companies. The Diversified board of directors hired Wilmer, Cutler \& Pickering, a Washington, D.C. law firm, to investigate these charges. ${ }^{81}$ The law firm interviewed many Diversified employees and eventually produced a memorandum for the board. ${ }^{82}$ Diversified surrendered a copy of this memorandum to the SEC in response to an agency subpoena, and subsequently entered into a consent decree with the Commission. At the same time, the Weatherhead Company filed suit against Diversified for allegedly bribing Weatherhead's purchasing agents with the slush

78 Sealed Case, 676 F.2d at 819.

${ }^{79}$ See In re Penn Cent. Commercial Paper Litig., 6I F.R.D. 453 (S.D.N.Y. 1973). Penn Central involved a private SEC investigation of the Penn Central Transportation Company, during which the Commission subpoenaed documents from a member of a law firm that had represented certain investment banking concerns in connection with Penn Central debenture offerings. The law firm produced the requested documents and two of its attorneys testified before the Commission. In a subsequent private suit against one of the law firm's clients, plaintiffs attempted to gain access to the information that had been disclosed to the SEC. The defendants argued that the information was protected by the attorney-client privilege, claiming that "disclosure in a nonpublic investigation does not waive the attorney-client privilege in later civil litigation." Id. 462. The court held that the privilege had been waived. The defendant's waiver argument, the court said, "would permit selective waiver of the privilege," an untenable result. Id. 463 . "Once the secrecy or confidentiality is destroyed by a voluntary disclosure to a third party, the rationale for granting the privilege in the first instance no longer applies." Id. (footnote omitted).

80572 F.2d 596 (8th Cir. 1978) (en banc).

81 Id. 600 .

82 Id. 600-01. 
fund, and sought production of the law firm's memorandum in discovery. ${ }^{83}$

The original panel found that the disputed memorandum was not covered by the attorney-client privilege because the law firm had not been hired to provide legal advice. ${ }^{84}$ On rehearing en banc, however, the court (led by the dissenter from the original panel) disagreed, and found that the law firm had provided legal advice. $^{85}$ The court also held that the interviewed employees fit within the framework of the attorney-client relationship, and in so doing rejected the "control group" test. ${ }^{86}$ Thus the en banc panel reached the issue of limited waiver, an issue that the original panel had touched only in dicta. ${ }^{57}$

With little discussion and scant precedential support, ${ }^{88}$ the court accepted Diversified's argument that disclosure of the memo-

83 Id. 599.

84 Id. 603. The court discussed the problem of the corporate client and reviewed both the "control group" test and the alternative Harper \& Row "subject matter" formulation, see supra note 23 , but found it unnecessary to resolve this issue. $572 \mathrm{~F} .2 \mathrm{~d}$ at $602-03$. In addition, the original panel held that the memorandum was not subject to the work-product privilege under FED. R. Crv. P. 26 (b) (3) because no suit had been filed, and thus the material had not been assembled "in anticipation of litigation." 572 F.2d at 604 . See supra note 61.

$85 \mathrm{Id} .610$.

86 Id. 608-09. The Diversified court's rejection of the "control group" test and its acceptance of the Harper \& Row standard (sometimes called the "subject matter" test), thus presaged the Supreme Court's decision in Upjohn Co. v. United States, 449 U.S. 383 (1981), by two years. See supra notes 19-23 and accompanying text.

\section{The original panel had indicated that it}

would be reluctant to hold that voluntary surrender of privileged material to a governmental agency in obedience to an agency subpoena constitutes a waiver of the privilege for all purposes, including its use in subsequent private litigation in which the material is sought to be used against the party which yielded it to the agency.

572 F.2d at 604 n.1.

88 The court teached its conclusion with only two supporting citations, see id. 611, both marginally related to the issue at hand. In Bucks County Bank \& Trust Co. v. Storck, 397 F. Supp. 1122 (D. Hawaii 1969), the issue was whether waiver of the privilege at a suppression hearing operated as a general waiver, while United States v. Goodman, 289 F.2d 256 (4th Cir.), vacated on other grounds, 368 U.S. 14 (I961), did not involve the attorney-client privilege at all, but rather the fifth amendment privilege against self-incrimination. In $r e$ Penn Cent. Commercial Litig., 61 F.R.D. 453 (S.D.N.Y. 1973), was thus the first case to address the issue of limited waiver of the attomey-client privilege head-on, and the first to involve waiver in the context of an SEC investigation. See supra note 79. The en banc opinion in Diversified failed to mention Penn Central, which had rejected the limited waiver theory. Judge Heaney, who wrote the en banc opinion, did not make the same mistake in his dissent from the original panel's opinion, which cited Penn Central as precedent against the principle of limited waiver. $572 \mathrm{~F} .2 \mathrm{~d}$ at 604 (Heaney, J., dissenting). 
randum to the SEC did not constitute a general waiver of the attorney-client privilege. The court declared that

[a]s Diversified disclosed these documents in a separate and nonpublic SEC investigation, we conclude that only a limited waiver of the privilege occurred. . . . To hold otherwise may have the effect of thwarting the developing procedure of corporations to employ independent outside counsel to investigate and advise them in order to protect stockholders, potential stockholders and customers. ${ }^{89}$

The majority's unspoken assumption was that corporations would be unwilling to invoke the attorney-client privilege to protect their internal investigations from the scrutiny of the SEC. The author of the original opinion dissented from the en banc result but agreed that "the privileges claimed by Diversified, if originally extant, were not waived by the voluntary disclosures made by Diversified to the Securities \& Exchange Commission." 90

The Diversified opinion sparked much commentary in the legal field, but mostly for its treatment of the problem of the corporate client. ${ }^{91}$ Two subsequent district court cases, ${ }^{92}$ however, not only applied but also appeared to expand Diversified's limited waiver doctrine. Although the Diversified court's sole justification for embracing limited waiver was to encourage corporations to undertake internal investigations, ${ }^{93}$ the district court opinions framed the rationale for the limited waiver theory in terms of encouraging voluntary cooperation with government agencies ${ }^{24}$-a considerably

89572 F.2d at 611 (citations omitted).

90572 F.2d at 612.

91 See, e.g., Note, The Corporate Attomey-Client Privilege-A Compromise Solution: Diversified Industries v. Meredith, 11 ConN. L. Rev. 94 (1978); Note, The Attorney-Client Privilege: A Look At Its Effect on the Corporate Client and the Corporate Executive, 55 IND. L.J. 407 (1980); Note, Attorney-Client Privilege-Diversified Industries, Inc. v. Meredith: New Rules For Applying the Privilege When the Client Is a Corporation, 57 N.C.L. REv. 306 (1979); 28 Drake L. Rev. 191 (1978-79); 33 Vand. L. Rev. 999 (1980); 31 Vand. L. Rev. 667 (1978).

92 In re Grand Jury Subpoena Dated July 13, 1979, 478 F. Supp. 368 (E.D. Wis. 1979); Byrnes v. IDS Realty Trust, 85 F.R.D. 679 (S.D.N.Y. 1980). Cf. In re Weiss, 596 F.2d 1185, 1186 (4th Cir. 1979) (finding disclosure to SEC effected complete rather than limited waiver and requiring attorney to testify before grand jury: distinguishing Diversified as case involving private litigation and therefore not requiring "judicial intervention in the grand jury process").

${ }^{93}$ See supra text accompanying note 89.

94 478 F. Supp. at 372-73; 85 F.R.D. at 688 . Grand Jury Subpoena involved an internal investigation, 478 F. Supp. at $370-71$, but Byrnes did not, 85 F.R.D. at 681-82. The Bymes court rejected the argument that the Diversified limited waiver theory applied only to "corporate housecleanings." Id. 688. See also In re Sealed Case, 676 F.2d 793, 823-24 (D.C. Cir. 1982). Interestingly, the 
broader public policy goal than merely encouraging corporations to police themselves.

In Teachers Insurance of Annuity Association of America $v$. Shamrock Broadcasting Co. ${ }^{95}$ another case dealing directly with the issue of limited waiver in an SEC investigation, the court initially seemed to read the Diversified opinion as confining limited waiver to situations involving internal corporate investigations. The court noted that "the reliance of the Diversified court on the need to encourage hiring of outside counsel to investigate suspected instances of corporate conduct [sic] is inapposite here," ${ }^{96}$ because the company had not conducted its own investigation. Nevertheless, the Teachers court's ultimate conclusion did not hinge on the presence or absence of an internal investigation: the court held that the attorney-client privilege had been waived because the plaintiff had not asserted the privilege in response to the SEG subpoena. "[D]isclosure to the SEC should be deemed to be a complete waiver of the attorney-client privilege unless the right to assert the privilege in subsequent proceedings is specifically reserved at the time disclosure is made." ${ }^{97}$ Although the Teachers opinion labelled this formulation "a third alternative" to general waiver and limited waiver, ${ }^{98}$ the outcome is essentially the same as that in Diversified, for under this ruling no party willingly would surrender privileged documents to the SEC without first obtaining "a protective order, stipulation, or other express reservation of the producing party's claim of privilege as to the material disclosed." 99 The Teachers approach rests the outcome on whether a party intended to waive the privilege. A party's intention to waive or not to waive the privilege, however, is generally not considered determinative of whether a waiver actually has taken place: "A privileged person

original Diversified opinion (as opposed to the en banc opinion) also identified furthering voluntary cooperation with government agencies as the goal of limited waiver. See supra note 87.

95521 F. Supp. 638 (S.D.N.Y. 1981).

$96 \mathrm{Id}$. 645.

${ }^{97}$ Id. See also Sealed Case, 676 F.2d at 824 ("In the final analysis, Diversified goes much farther than necessary to accomplish its objective. The SEC or any other government agency could expressly agree to any limits on disclosure to other agencies consistent with their responsibilities under law. But courts should not imply such agreements on a categorical basis.") (footnote omitted).

98521 F. Supp. at 646.

${ }^{99} \mathrm{Id}$. See also Note, supra note 63 , at 985-87 (reaching an identical conclusion). In almost any circumstance the SEC would have no reason to refuse such a stipulation; the agency receives the documents it has demanded, and which otherwise would be unavailable, with only minor inconvenience. 
would seldom be found to waive, if his intention not to abandon could alone control the situation." 100

\section{B. Permian}

The Diversified limited waiver theory stood essentially unchallenged until the District of Columbia Circuit decided the case of Permian Corp. $v$. United States. ${ }^{101}$ The Permian case developed from Occidental Petroleum's unsuccessful attempt to take over the Mead Corporation. Mead had opposed Occidental's proposed exchange offer, and initiated litigation to prevent the takeover. During the course of discovery, Occidental produced over two million documents in response to Mead's requests. ${ }^{102}$

At the same time, the SEC found itself buried under a similar avalanche of Occidental documents during its consideration of Occidental's registration statement for the proposed exchange offer. "The SEC made it clear that processing of the registration statement would be greatly facilitated by access to Occidental documents presifted by Mead; without that access, considerable delay could result." 103 Occidental acceded to this request, subject to certain procedural safeguards designed to protect Occidental's privileges. ${ }^{104}$ Occidental ultimately abandoned its exchange offer, but not before Mead had submitted one thousand Occidental documents to the SEC. Thirty-six of the documents dealt with the legality of oilpricing policy at Permian, an Occidental subsidiary; the instant litigation began when Occidental objected to a request by the

$1008 \mathrm{~J}$. WIGMORE, supra note $1, \S 2327$, at 636 .

101665 F.2d 1214 (D.C. Cir. 1981).

102 To prevent inadvertent waiver of the privilege, Occidental and Mead stipulated that "inadvertent production of a privileged document would not constitute a waiver of the privilege." Id. 1216.

103 Id.

104 According to counsel for Occidental, Mead had been permitted to release Occidental documents received in discovery to the SEC, but had been required to inform Occidental which documents had been delivered within forty-eight hours. Each document was to have been stamped with the following legend:

This Document constitutes a Trade Secret and/or Commercial or Financial Information which is Privileged and Confidential and May not be Released or Disclosed.

Pursuant to procedures adopted by Occidental \& the Securities \& Exchange Commission, this Document may not be disclosed by the Commission to any third-party unless prior notice of such proposed disclosure has been given to Occidental.

Id. The Permian court found that Occidental's interpretation of its agreement with the SEC was correct, id. 1219, but held that the agreement could not prevent a waiver of the attomey-client privilege. It is interesting to note, however, that this agreement between Occidental and the SEC would have satisfied the requirement of the Teachers court that the privilege be "specifically reserved." 521 F. Supp. at 645. See supra text accompanying notes 95-100. 
Department of Energy for those thirty-six documents. ${ }^{105}$ The Permian court ruled that the attorney-client privilege had been waived as to the documents, but that the work product doctrine ${ }^{106}$ covered twenty-nine of the thirty-six documents. ${ }^{107}$ Thus, the Department of Energy was allowed access to only seven of the documents it had sought.

Addressing Occidental's attorney-client privilege claim, the Permian court declared that "Occidental asks this court to create an exception to the traditional standard for waiver by adopting the 'limited waiver' theory of Diversified Industries, Inc. v. Meredith ... [but] we find the 'limited waiver' theory wholly unpersuasive." 108 The court noted that the theory of limited waiver does not serve the principles underlying the attorney-client privilege, ${ }^{109}$ and rejected "the argument that some public policy imperative inherent in the SEC's regulatory program requires that the traditional waiver doctrine be overridden." 110 The attorney-client privilege, said the court, "should be available only at the traditional price: a litigant who wishes to assert confidentiality must maintain genuine confidentiality." 111 Thus the court pointedly disagreed with the Eighth Circuit's reasoning in Diversified in reaching its result. ${ }^{112}$

$105665 \mathrm{~F} .2 \mathrm{~d}$ at 1217. The court noted that Mead turned these documents over to the SEC three days before informing Occidental, id., but did not find this fact significant because "Occidental did not request that they be returned unread." Id. 1210.

100 See supra note 61.

107665 F.2d at 1222.

108 Id. 1220.

$109 \mathrm{Id}$. ("The Eighth Circuit's limited waiver rule has little to do with the confidential link between the client and his legal advisor.")

110 Id. 1221.

$111 \mathrm{Id} .1222$.

112 The Second Circuit recently reached a similar conclusion in In re John Doe Corp., 675 F.2d 482 (2d Cir. 1982), a case involving a corporation's internal investigation-at the request of the SEC, id. $484 \mathrm{n.2}$-of an alleged attempt by the corporation to bribe a public official. The report resulting from the investigation was disclosed, not to the SEC, but to an accounting firm conducting an audit and to a lawyer representing an underwriter in connection with a public offering of the corporation's securities. Id. 485. In addition, a member of the accounting firm discussed the alleged bribe with the corporation's general counsel. The court held that this latter conversation and the disclosure of the report to counsel for the underwriter waived the attorney-client privilege because they had taken place "for reasons other than seeking legal advice." Id. 488. The court endorsed Permian's rejection of "a 'pick-and-choose" theory of attorney-client privilege," finding the case before it "somewhat stronger since it does not involve an agreement with a governmental agency purporting to protect the privilege so far as other agencies are concerned." Id. 489 (quoting Permian Corp. v. United States, 665 F.2d 1214, 1221-22 (D.C. Cir. 1981)). See also In re Weiss, 596 F.2d 1185 (4th Cir. 1979) (testimony by an attorney before SEC waived privilege in later grand jury proceeding); In re Penn Cent. Commercial Paper Litig., 61 F.R.D. 453 (S.D.N.Y. 1973), discussed supra note 79. 


\section{ANalysis of Limited Waiver}

The doctrine of limited waiver of the attorney-client privilege represents a clear departure from the privilege's general requirement of confidentiality. ${ }^{113}$ In order to determine whether such an exception should be made, the potential benefits of accepting the doctrine must be weighed against the costs. ${ }^{114}$ The costs to the judicial system are obvious: limited waiver deprives the courts of relevant information that would otherwise be available if the privilege were deemed waived. Limited waiver would thus protect privileged information as to which confidentiality is not important to the client, making the privilege broader than necessary. ${ }^{115}$

The benefits of limited waiver to the client are equally obvious: an individual or corporation could choose to disclose privileged information when disclosure appears advantageous, while retaining the privilege to deny other parties access to the information. Attorneys, too, might benefit from limited waiver through increased legal consultation. Benefits to attorneys and clients, however, do not provide support for either the privilege itself or for limited waiver. The attorney-client privilege would exist even if attorneys and clients were indifferent to it, because it provides other benefits to society in the form of potential improvements in the administration of justice. ${ }^{110}$ Similarly, the limited waiver theory must be justified by advantages accruing to society as a whole. Courts that have addressed the question have identified two such potential advantages: increased internal corporate investigations and facilitation of administrative agencies' functions. ${ }^{117}$

Until now the theory of limited waiver has been discussed as a static concept, but the theory can assume many possible formulations. The balancing considerations for and against limited waiver may weigh differently for each possible theoretical formulation; the next problem is to determine to what extent, if at all, a theory of limited waiver should apply.

113 See supra text accompanying notes 55-61.

114 " $[\mathrm{T}]$ he instrumental underpinnings of the modern attorney-client privilege seem to require that courts adhere to a consistent practice of weighing the benefits to be gained by applying the privilege against the costs of excluding evidence ...." Note, supra note 37 , at 468 .

115 See supra text accompanying notes 62-66.

116 See supra text accompanying notes 38-42. See also Upjohn Co. v. United States, 449 U.S. 383, 389 (1981) (purpose of attorney-client privilege "is to encourage full and frank communication between attorneys and their clients and thereby promote broader public interests in the observance of law and administration of justice").

117 See supra text accompanying notes $89-94$. 


\section{A. The Limits of Limited Waiver}

For the purposes of this Comment, four types of limited waiver will be considered: a general limited waiver, a selective administrative limited waiver, an overall administrative limited waiver, and a limited waiver only for the Securities and Exchange Commission.

\section{General Limited Waiver}

A general theory of limited waiver is really not a theory of waiver at all. Under this formulation, the usual rules regarding waiver of. a privilege ${ }^{118}$ would be discarded, and breach of the confidentiality underlying the attorney-client privilege in one setting or to one party would never effect a waiver of the privilege as to any other party or in any other proceeding. In other words, a party could divulge privileged information selectively to anyone without ever waiving the attorney-client privilege.

\section{Selective Administrative Limited Waiver}

A selective administrative limited waiver would allow a party to reveal privileged confidential material to any federal administrative agency without waiving the attorney-client privilege as to any private party or as to any other administrative agency. This formulation would be narrower than the general theory of limited waiver, because production of the confidential information to a private party would still result in the usual waiver of the privilege. Selective administrative limited waiver would not recognize any characteristics of the SEC situation as unique, treating all federal administrative agencies in a similar fashion.

\section{Overall Administrative Limited Waiver}

Under a theory of overall administrative limited waiver, production of privileged information to an administrative agency would operate as a waiver of the privilege as to all federal administrative agencies, but would not serve as a waiver of the privilege as to other parties. As with selective administrative limited waiver, this alternative would not distinguish between administrative agencies. An overall administrative limited waiver would also be the only theory that would harmonize the contrary results in Permian Corp. 
v. United States ${ }^{119}$ and Diversified Industries, Inc. v. Meredith..$^{120}$ Production to a private party would again operate as a general waiver.

\section{Limited Waiver Only For the SEC}

Under limited waiver only for the SEG, production to the SEC would not effect a waiver of the attorney-client privilege as to any other party, but production to other parties, including other administrative agencies, would effect a general waiver. Limited waiver for the SEG would be premised on the notion that there are certain characteristics unique to an SEC investigation, ${ }^{121}$ and would encourage production of privileged documents to that agency above all others.

\section{Analysis of the Alternatives}

The first theory presented, general limited waiver, cannot be accepted because it is clearly too broad. The rationales offered to support a theory of limited waiver do not apply to the general limited waiver formulation. The primary justification for limited waiver lies in the public policy of encouraging cooperation with an administrative agency and compliance with its subpoena. ${ }^{122}$ This public policy goal is not served when privileged material is surrendered to a private party, but the cost to the evidentiary process under general limited waiver remains the same. General limited waiver thus must be rejected.

The doctrine of overall administrative limited waiver would cure the objection that "a doctrine of limited waiver would enable litigants to pick and choose among regulatory agencies in disclosing and withholding communications of tarnished confidentiality for their own purposes." 123 Overall administrative limited waiver, however, would give governmental agencies a decided advantage over private parties in the evidentiary process. There is nothing in the background of the attorney-client privilege that would justify such a result. Within the limits of legislative authorization, the

119665 F.2d 1214 (D.C. Cir. 1981).

120572 F.2d 596 (8th Cir. 1978) (en banc). Both Permian and Diversified involved release of privileged documents to the SEC, but in Permian the third party that later sought the documents was another regulatory agency (the FTC), while in Diversified the third party was a private litigant. The Diversified court accepted the limited waiver theory; the Permian court rejected it.

121 Another possibility that will not be discussed would be overall administrative limited waiver only for the SEC.

122 See supra text following note 92.

123 Permian, 665 F.2d at 1221-22. 
judicial system should not discriminate between private parties and government agencies; justice demands that all litigants be treated by the same rules. In addition, overall administrative limited waiver would be a much broader exception to the confidentiality requirement ${ }^{124}$ than selective administrative limited waiver, in that not just one but all government agencies would have access to privileged material. Overall administrative limited waiver would also create a problem for the courts when public interest groups, such as the American Civil Liberties Union or the NAACP, are involved, for public interest groups could legitimately claim that public policy supports their functions as much as those of regulatory agencies.

Furthermore, the theory of overall administrative limited waiver would not necessarily further the goal of promoting voluntary cooperation with government agencies, as the Permian scenario suggests. ${ }^{125}$ If a federal administrative agency presses a corporation for production of a privileged document that the corporation does not want another agency to see, the corporation may choose not to surrender the documents at all rather than to allow every agency to have access to the privileged information. Overall administrative limited waiver thus does not achieve the maximum public policy benefit available under limited waiver and imposes a greater cost on the integrity of the evidentiary process; therefore, it should be rejected as inferior to selective administrative limited waiver.

The difference between the two remaining theories, selective administrative limited waiver and limited waiver only for the SEC, is in the range of situations in which limited waiver can be invoked. The question, then, is whether there are any considerations unique to an SEG investigation, or whether all federal administrative agencies (including the SEC) should be treated alike.

The public policy objective identified by the Diversified court -that of encouraging corporations to undertake their own internal investigations ${ }^{126}$-might be better served by limited waiver only for the SEC if the SEC were more likely than other government agencies to request access to the fruits of those investigations. While this has been true of the SEG in the past, nothing prevents other administrative agencies from instituting their own "voluntary disclosure" programs. ${ }^{127}$ Moreover, the public policy of encourag-

124 See supra text accompanying notes 55-66.

125 See supra text accompanying notes 101-11.

126 See supra text accompanying note 89.

127 See supra text accompanying notes 75-78. It should be noted, however, that the SEC, unlike other agencies, is primarily interested in full disclosure. See infra note 130. 
ing cooperation with agency investigations appears to be no stronger for the SEC than for any other administrative agency; there is "no congressional directive or judicially-recognized priority system that places a higher value on cooperation with the SEC than on cooperation with other regulatory agencies." 128 In the specific instance of the Permian case, for example, the public benefit derived from Occidental's production of the disputed documents to the SEC would be limited to present and prospective stockholders of the two corporations, ${ }^{129}$ while production of the same documents (dealing with the legality of Permian's oil-pricing strategy) to the Federal Trade Commission could benefit a broad range of consumers. From a public policy perspective, then, there seems to be no reason to distinguish between the SEC and other regulatory agencies for the purposes of limited waiver.

In one sense, however, production to the SEC may be easier to encourage than production to other federal agencies, because the SEC is not generally a prosecutorial agency. ${ }^{130}$ Its mission is to supervise full disclosure, not to pass judgment on the legality of various questionable corporate practices. A corporation, then, may be more willing to cooperate with the SEC than with other regulatory agencies, because the SEC would only wish to compare for accuracy the privileged information to information in the corporation's registration statement. This fact alone, however, would not seem to justify the creation of a special evidentiary privilege for a corporation that faces an SEC subpoena. It is of interest only to the corporation, and not to the judicial system, that cooperation with an SEC subpoena or request may entail less unpleasant consequences than cooperation with the subpoena of any other federal administrative agency.

On the other hand, the consequences of resisting an SEC subpoena or request may be more unpleasant than the consequences of resisting other agencies' demands. The SEC has the power to block or impede a corporation's access to capital markets by delay-

128 Permian, 665 F.2d at 1221.

129 Stockholders of a corporation would always seem to benefit when that corporation's registration statement becomes effective.

130 The Securities Exchange Act of 1934, codified as amended at 15 U.S.C. $\$ 78 \mathrm{a}-77 \mathrm{jj}$ (1976), and the Securities Act of 1933, codified as amended at 15 U.S.C. $\$ 77 \mathrm{a}-77 \mathrm{bbbb}$ (1976), authorize the SEC to supervise the filing of registration statements that disclose all material facts about a corporation's financial position. See E. Thomas \& R. Shrelds, Federar Securities Act Handbook 13 (4th ed. 1977) (the Securities Act "does not empower the SEC to pass upon the merits of securities. It is a 'disclosure' statute."). After an investigation, however, the SEC may refer a case to other governmental authorities for civil prosecution or to the Department of Justice for criminal prosecution. Id. 229. 
ing approval of its registration statement. ${ }^{131}$ In Permian, for example, the SEC suggested that allowing the Commission access to privileged documents would expedite review of Occidental's registration statement for Mead stock. ${ }^{132}$ The district court in that case concluded that the SEC's "repeated request" made the decision to supply the documents "Iess than voluntary." ${ }^{133}$

This observation raises the possibility that disclosure to the SEC should be deemed to fall into the "voluntariness" exception to the waiver rule, which holds that an involuntary breach of confidentiality does not waive the attorney-client privilege. ${ }^{134}$ In In re John Doe Corp., ${ }^{135}$ a similar claim was rejected by the Second Circuit. The corporation argued that its disclosure of an internal report to counsel for an underwriter "was not voluntary because it was coerced by the legal duty of due diligence and the millions of dollars riding on the public offering of registered securities." 136 The court viewed this argument "with no sympathy whatsoever," holding that "[o]nce a corporate decision is made to disclose [privileged communications] for commercial purposes, no matter what the economic imperatives, the privilege is lost ..." 137 The John Doe approach is clearly consistent with the traditional standard for

131 The SEC can delay a corporation's registration statement by successive requests for amendment. Each required amendment delays the effective date of the registration statement until twenty days after the amendment is complete. Thus, the Commission could theoretically delay a registration statement indefinitely by continued requests for amendment. In addition, the Commission might refuse to accelerate the effective date of the issuer's price amendment, and no undervititer would participate in an offering in which the price was set twenty days before the security could be sold.

132 See supra text accompanying notes 103-04.

133 Permian Corp. v. United States, [1980 Transfer Binder] FEd. SEc. L. Rep. (CCH) T 97,523 (D.D.C. May 15, 1980) (summary), rev'd in part, 665 F.2d 1214 (D.C. Cir. 1981). The circuit court reversed on this point, however, declaring that "[i]f Occidental's massive and amorphous response to the SEC's information requests necessitated lengthy review ... then Occidental's acquiescence can only be attributed to its own preference for swifter approval of the registration statement at the risk of disclosure of confidential communications." Id. I221 n.14.

134 See supra text accompanying notes 71-74. See also Comment, Corporate Self-Investigations Under the Foreign Corrupt Practices Act, 47 U. CHI. L. Rev. 803,807 n.16, 810-11 (arguing that disclosure to SEC is compelled by regulatory obligations and is therefore not "voluntary"); cf. United States v. New Wrinkle, Inc., 1954 Trade Cas. (CCH) $₫ 67,883$ (S.D. Ohio 1954) (presence of government agents in place of business involves "implied coercion" and makes surrender of documents involuntary).

135675 F.2d 482 (2d Cir. 1982). See also United States v. Upjohn Co., 600 F.2d 1223, 1227 n.12 (6th Cir. 1979), rev'd on other grounds, 449 U.S. 383 (1981).

136675 F.2d at 489.

137 Id. 
involuntary waiver of the attorney-client privilege, which requires either judicial compulsion ${ }^{138}$ or the involvement of a third party such as an eavesdropper. ${ }^{139}$ Like the decision to disclose a report to an underwriter, the decision to turn over privileged communications to the SEG is a considered choice made in order to avoid unpleasant economic consequences. ${ }^{140}$ The argument that such a waiver of the privilege is involuntary therefore should be rejected.

Another variation on the involuntariness argument focuses on the broad discretionary powers of the SEC. The SEG has the potential to penalize an uncooperative corporation in a number of ways, such as by damaging its business reputation and relationships, or by suspending trading in its stock for ten days. ${ }^{141}$ A waiver induced by fear of improper official action might indeed be considered involuntary, and therefore not a waiver at all. ${ }^{142}$ There is, however, no proof that the SEC abuses its discretion in retaliation for a corporation's invocation of the attorney-client privilege. ${ }^{143}$ Moreover, the SEC is not the only agency with broad discretion. ${ }^{144}$ If disclosure to the SEC is deemed involuntary, the same reasoning would have to apply to disclosures to other agencies as well. Even if proof of widespread abuse of governmental discretion existed, justifying a general theory of limited waiver on these grounds would amount to a tacit acceptance of improper official action. Thus,

138 But cf. Transamerica Computer Co. v. IBM, 573 F.2d 646, 651 (9th Cir. 1978) (disclosure of privileged documents under "extraordinary" accelerated discovery proceedings not voluntary).

139 See supra note 74 and accompanying text.

140 This balancing of the possible results by the corporation seems very similar to the well-entrenched system of plea bargaining. While some commentators might argue that plea bargaining does not produce "voluntary" pleas, it is generally accepted that negotiated pleas are in fact voluntary. See, e.g., North Carolina v. Alford, 400 U.S. 25,33 (1970) (decision to accept a plea bargain was based on defendant's preference that "the dispute between him and the state ... be settled by a judge in the context of a guilty plea proceeding rather than by a formal trial"); United States v. Howell, 661 F.2d 96, 97 (8th Cir. 1981); United States v. Law, 633 F.2d 1156, 1157 (5th Cir. 1981).

141 Rowe, Representing a Public Corporation Involved in an SEC Investigation, in Practicing LaW INSTITUTE, HaNdLING aN SEC INVEstigation 1980 1920 (1980).

142 Cf. Dix, Waiver in Criminal Procedure: A Brief for More Careful Analysis, 55 TEx. L. REv. 193, 243 (1977) (general agreement that waiver of a right is ineffective if induced by defendant's perception that failure to waive would result in improper official action to his detriment).

143 Stanley Sporkin, former Director of the SEC's Enforcement Division, has denied that the Commission uses its administrative powers to coerce corporations into revealing privileged documents; rather, he feels, corporations generally divulge privileged information to the SEC because it is in their interest to have the SEC (but no one else) see it. Interview with Stanley Sporkin (Mar. 18, 1982). (1879).

144 See K. Davas, 2 Treatise ON Admonistrative Law $\$ 8.3$, at 163-67 
disclosure to the SEC or to any administrative agency cannot be considered involuntary, at least in the absence of proven specific instances of coercion.

In sum, the case for limited waiver appears neither stronger nor weaker for the SEC than for any other federal agency. If a theory of limited waiver is to be accepted, then, it cannot be confined to the SEC situation. The case law, however, seems to have centered on instances of cooperation with the SEC. ${ }^{145}$ This Comment will therefore focus on the theory of limited waiver of the attorney-client privilege in an SEG investigation, with the understanding that the result and the reasoning are generally applicable to other federal administrative agencies through the theory of selective administrative limited waiver.

\section{B. The Arguments for and Against Limited Waiver}

The justification for limited waiver rests primarily on the desirability of encouraging production of privileged documents to the SEC. The SEC's function is to ensure that the investing public is provided with truthful and complete data on the financial condition of their investments, and the Commission's task may become more difficult without access to privileged documents. Because the SEC is a public agency, its efficiency is a matter of public concern. It is thus in the public interest to encourage production of privileged documents to the SEC.

Limited waiver might encourage such disclosures if a corporation has not committed any acts that fall within the SEG's jurisdiction, but has secrets that might be of interest to another regulatory agency ${ }^{146}$ or to a private party. ${ }^{147}$ In such a situation, limited waiver removes the disincentive for complying with an SEC subpoena, and may spur a corporation to surrender the subpoenaed documents to end the SEG investigation. ${ }^{148}$

Limited waiver might also produce a less direct benefit by encouraging corporations to conduct internal investigations. Limited

145 This may be true because the SEC seeks information on a broad range of topics, but uses that information only for the limited purpose of verifying the accuracy of financial statements and required disclosures.

146 E.g., Permian Corp. v. United States, 665 F.2d 1214 (D.C. Cir. 1981). banc).

147 E.g., Diversified Indus. v. Meredith, 572 F.2d 596 (8th Cir. 1978) (en

148 Even if the corporation has nothing to hide from the SEC in the instant investigation, it still might refuse to surrender privileged material to avoid setting a bad precedent: not surrendering privileged material in a subsequent investigation might arouse the SEC's suspicion. 
waiver would be most likely to have this effect when the SEG asks a corporation to conduct an investigation in order to spare the SEC staff time and effort. Corporate managers are unlikely to agree to unearth instances of corporate misconduct for the SEC if they know that others will have access to the information. ${ }^{149}$ Their refusal to investigate will, in turn, increase the regulatory burden on the SEC and possibly result in fewer investigations being conducted. The availability of limited waiver may not, however, have any effect on corporate managers' decisions to undertake internal investigations for other reasons. Managers and directors might, for example, launch an investigation in order to fulfill their fiduciary obligations to shareholders or to forestall an SEC investigation. ${ }^{150}$ In this situation, the corporation can preserve the confidentiality of its documents by simply invoking the attorney-client privilege in response to an agency subpoena.

The last argument in favor of limited waiver relates to the nature of the privilege itself. The attorney-client privilege prevents disclosure of communications but does not protect the secrecy of the underlying facts. ${ }^{151}$ An adversary is not foreclosed from deposing witnesses and asking the same questions that the client's attorney has asked, or from issuing subpoenas for the same internal memoranda that the attorney has inspected. Limited waiver, then, would make the adversary's task decidedly more difficult, but would not constitute an absolute bar to discovery of the privileged information.

Against these arguments, however, must be weighed the cost that limited waiver imposes on the evidentiary process. Privileges in general are an exception to the normal rules of evidence because the judicial system, through the rules of discovery, requires each party to submit all evidence that is relevant to the resolution of a dispute. The judicial system tolerates certain privileges because it is supposed that the system will benefit from encouraging the confidentiality of privileged relationships more than it will suffer from the withdrawal of the privileged information from the factfinding process. ${ }^{152}$ The benefits of the privilege, however, are unproven, particularly as they apply to corporations. ${ }^{153}$ Limited waiver, by

149 Cf. Note, supra note 24 , at 1178 .

150 See Block \& Barton, supra note 77, at 7-8.

151 See supra notes $32-33$ and accompanying text. But see infra note 158 and accompanying text.

152 See supra text accompanying notes $38-42$.

153 See supra text accompanying notes 46-54. 
diluting the confidentiality requirement, increases the availability of the privilege to the very clients who are least likely to need it.

The ultimate purpose of the attorney-client privilege is to improve the attorney-client relationship, thereby furthering the administration of justice. The purpose of limited waiver, on the other hand, is the facilitation of the administrative function of the SEC or other government agencies. ${ }^{154}$ Although such a goal may be socially worthwhile, the judicial system does not tailor its results to achieve social benefits in every imaginable situation..$^{155}$

The argument that facilitation of the SEC's functions is a judicially recognizable priority can be answered in a number of ways. First, the SEC already possesses a broad range of investigative powers and sanctions, ${ }^{156}$ and may not have much need for additional procedural tools for acquiring information. Second, there are many alternative ways to increase the SEC's ability to acquire information, one of which would be for Congress to declare the attorney-client privilege inapplicable in all SEC proceedings. ${ }^{157}$ Third, by granting the SEC certain investigatory powers, Congress implicitly expressed a desire to allow the agency to reach a certain amount of evidence and no more. It may not be the courts' function to increase these implied limits on the agency's ability to procure information. And fourth, even if the corporation asserts its privilege the SEC may unearth the underlying facts on its own by deposing

154 See supra text following note 145.

155 See Permian, 665 F.2d at 1221 ("[W]e cannot see how the availability of a limited waiver' would serve the interests underlying the common law privilege for confidential communications between attorney and client. ... Voluntary cooperation with government investigations may be a laudable activity, but it is hard to understand how such conduct improves the attorney-client relationship.").

156 See Rowe, supra note 141, at 19-20.

157 As already mentioned, the attorney-client privilege does not have a constitutional dimension in civil cases, and could be withdrawn entirely at Congress' whim. See supra note 37. Limited waiver might be appropriate if promulgated by the legislative branch, however, because

Congress is more sensitively tuned to the competing social interests that demand accommodation and because the institutional legitimacy of a legislative act depends not so much on the rational persuasiveness of its decisions as on the simple fact that a majority of "responsible" elected officials were willing to vote for the proposition.

Burt, Miranda and Title II-A Morganatic Marriage, 1969 S. CT. REv. 81, 114. These considerations lead to the conclusion that "the Court should often defer to the ability of Congress to effectuate a more precise compromise of competing interests." Dellinger, Of Rights and Remedies: The Constitution as a Sword, 85 Harv. L. REv. 1532, 1549 (1972) (footnote omitted). Congress already prescribes rules of evidence for the federal judiciary, and could adopt a doctrine of limited waiver if it so desired. 
the same witnesses that the attorney had questioned and subpoenaing the same documents that the attorney had used. ${ }^{158}$

A second argument against limited waiver is a variation of the fairness argument that courts have accepted in the form of the "subject matter" waiver rule. ${ }^{159}$ Just as selectivity about which parts of a privileged communication to reveal is an impermissible "offensive" use of the privilege, so is selectivity about which parties to reveal the communication to. Both kinds of selective disclosure are attempts to gain tactical advantages from a privilege "intended only as an incidental means of defense." 160 The Permian court's construction of the fairness argument declared:

[C]ourts have been vigilant to prevent litigants from converting the privilege into a tool for selective disclosure. ... The client cannot be permitted to pick and choose among his opponents, waiving the privilege for some and resurrecting the claim of confidentiality to obstruct others, or to invoke the privilege as to communications whose confidentiality has already been compromised for his own benefit. . . . The attorney-client privilege is not designed for such tactical employment. ${ }^{161}$

The Permian court thus viewed confidentiality as the "traditional price" 162 of the attorney-client privilege.

In the usual limited waiver situation, the client is not concerned with the absolute confidentiality of the communications. ${ }^{163}$ Rather, the client corporation wishes to prevent others from using the information contained in the privileged documents against the corporation. This is not necessarily true of other attorney-client situations, where confidentiality may be important to the client.

158 See supra text accompanying notes 32-33. "Litigants may still examine business documents, depose corporate employees and interview nonemployees, [and] obtain preexisting documents and financial records. . . ." Diversified, 572 F.2d at 611. The Diversified court used this argument in favor of limited waiver, but it seems to provide strong reasons against that doctrine. Other litigants are less likely than regulatory agencies to have the resources necessary to dig through all the possible sources for the relevant information. Limited waiver, then, would add to the information-seeking capability of those who need it least-federal agencies.

159 See supra text accompanying notes 67-70.

$1608 \mathrm{~J}$. WIGMORE, supra note $1, \S 2327$, at 638 . But see Note, supra note 63 , at 981 ("Because the limited waiver situation involves a full disclosure, there is no attempt to use the privilege offensively.").

161665 F.2d at 1221 (citations omitted).

162 Id. 1222.

163 If the client were concerned with absolute confidentiality, the privileged documents would not be surrendered to the SEC in any case. 
For example, in many instances outside knowledge of the content of privileged communications might be as damaging as having the privileged communications introduced into evidence, because that knowledge would lead to other evidence that could be used against the client. ${ }^{164}$ The requirement of confidentiality, then, cuts strongly against any doctrine of selective or limited waiver, because the justification for the privilege is to encourage disclosure to the attorney of information that would otherwise be kept secret. ${ }^{105}$

\section{Conclusion}

Although the goals of encouraging internal corporate investigations and voluntary cooperation with government agencies are laudable, the limited waiver doctrine is not an appropriate means of promoting them. Limited waiver represents an expansion of an evidentiary privilege that imposes obvious costs on the judicial system and offers only speculative benefits. Just as there is no proof that the attorney-client privilege induces clients to divulge confidences to their attorneys, there is little reason to believe that limited waiver of the privilege would increase the sum total of corporate investigations. While it seems more likely that limited waiver would encourage cooperation with government agencies, this possible benefit does not outweigh the doctrine's costs. Because the SEC has no greater claim to judicial solicitude than other government agencies, limited waiver cannot be confined to disclosures to the SEC. Thus, under limited waiver, the disclosure of privileged communications to any agency would not result in a waiver of the privilege as against third parties. The judicial system would be deprived of potentially vast quantities of relevant information as to which the privilege would otherwise be deemed waived. Moreover, the goal of furthering cooperation with government agencies is unrelated to the goal underlying the privilege itselfthat of furthering legal consultation.

The modern approach to the rules of evidence strongly favors the admission into evidence of all relevant information. The attorney-client privilege, like all exclusionary rules of evidence, should be narrowly construed: any voluntary breach of confidentiality

164 It has been recognized, for example, that the fifth amendment privilege against self-incrimination "not only extends to answers that would in themselves support a conviction under a federal criminal statute but likewise embraces those which would furmish a link in the chain of evidence needed to prosecute the claimant." Hoffman v. United States, 341 U.S. 479, 486 (1951) (citation omitted).

165 See supra text accompanying notes $38-41$. 
should constitute a waiver. A corporation should not be allowed to waive selectively the attorney-client privilege when waiver suits its purposes and to retain the privilege when it does not. The corporation should instead be required to decide whether it wishes to surrender privileged documents and waive the privilege, or retain the privilege and forego the benefit that it might have derived from selective disclosure. The doctrine of limited waiver should be rejected by the federal courts. 